\title{
EQUILATERAL TRIANGLE AND THE HOLY TRINITY
}

\author{
J. Krzysztof LENARTOWICZ \\ Faculty of Architecture, Cracow University of Technology, Ul. Warszawska 24, 31-155 Cracow, Poland \\ E-mail:klenart@pk.edu.pl
}

Received 06 October 2014; accepted 01 December 2014

\begin{abstract}
The paper deals with architectural space designed and/or built on an equilateral triangular plan, and designated for a sacred function. The author discusses the exceptional features of equilateral triangle in comparison to other central layouts. The visual attractiveness of this geometrical shape is stressed. The architectural space built on this figure has a strong semantic potential in Christian culture in Europe, since a sacred object using such a shape is associated in an easy and unambiguous manner, which also points to the popularity of patrocinium of the Holy Trinity, as well as that of the Virgin and Child with St. Anne, among the analysed structures. A comprehensive catalogue is presented of sacred objects based on an equilateral triangular plan, which have been identified in the European culture area, and were created in the period between the 12th century and contemporary times. At the nexus of the Eastern and Western Church, which differentiate their teachings in terms of interpreting the Holy Trinity (the problem of Filioque), the patrocinium and the erection of temples in the form discussed here has an exceptional meaning, especially if these shrines belong to the Uniate Church, which merges Catholicism and the Orthodox church. The types of the corner detailing have been analysed.
\end{abstract}

Keywords: sacred architecture, central plan, equilateral triangle, patrocinium, Holy Trinity, Filioque.

\section{Introduction}

To the "Vitruvian Triad", i.e. beauty (venustas), strength (firmitas), and function (utilitas), the three fundamental virtues of architecture as described in De Architectura Libri Decem, the 18th century added meaning (intellectus), and the 20th century - ecology (ecologia). Perfection in meeting all these five criteria is neither necessary nor possible in every building project. Balancing the virtues in a specific design project has been the architect's task since times immemorial. Two criteria, however, dominate in design of sacred objects - spatial and theological ones, which in relation to Vitruvius mean the superiority of form (venustas) and meaning (intellectus) over the remaining ones. Structure (firmitas), function (utilitas), and ecology (ecologia) are not crucial for the analysed objects, because the buildings neither serve prolonged stay of people, nor do exploitation advantages belong to basic requirements for them.
The study is devoted to sacred architectural space the form of which is based on equilateral triangular plan. The triangle defines the visual quality (venustas) of the entire object. The form is capable of transmitting meanings (intellectus). The present article summarizes the author's work ${ }^{1}$ carried since 2005 , and presents a comprehensive catalogue of sacred objects, which have been designed and built according to the compositional principle, organized in chronological order of their creation. Numbers in round parentheses, e.g. (034) refer to the catalogue list; bold numbers in square parentheses - to figures, e.g. (Fig. 3).

1 Lenartowicz $(2005,2009,2013)$, also at: http://www.zwojescrolls.com/zwoje44/ text23.htm. 


\section{Centralised space and its meaning}

Centralised space is a space organised in respect to a single point. All the axes crucial for function and form converge in the centre of the plan. This leads to the creation of manifold rotational symmetries of the layout. In consequence the composition around one point gives birth to a vertical axis derived from this point, this axis becoming the line of development of the entire composition. Every centralized spatial composition affects the viewer in a specific way. While architectural spaces of different, free, and decentred formal structure are positively perceived even with a relatively limited interior height, the centralized spaces demand bigger, even „unlimited” heights. It is so, because humans feel an invisible existence of the axis mundi (Norberg-Schulz 1971), which shoots upwards from the central point. The subconscious perception of the vertical direction wakes up an irresistible need to follow it, and consequently to crane one's neck up. This somatic reaction directly influences the feelings of the observer (Eberhard 2007). The reception is conjoined with certain elation, a positive feeling of transcendence. "A sacred space can be defined as any space (including spiritual places) that evokes special transcendent feelings within the visitor - a connection with something larger and deeper than our self" (Eberhard 2009a: 111). Our, currently available knowledge of the brain and mind can provide us with some plausible hypotheses about the cognitive and emotional experiences associated with a sacred space:

"Our sense of awe is influenced, in part, by having space above our head that is not visible until we move our eyes (and probably our head) upward. Semir Zeki once suggested that raising our eyes upward to see a spire on a cathedral was transformative - it stirs some primal notions of something ethereal." (Eberhard 2009b: 753-756).

The mechanism tying up form, proportion, and scale of space with foreseeable behaviour and positive emotions, once intuitively felt and applied by architects, today researched and proved by neurobiology today, was and still is effectively applied in sacred architecture devoted to God or otherwise understood Supreme Being 2 .

The power of the influence of centralised buildings was noticed long time ago. Such a composition heightens the monumentality of any object ${ }^{3}$. Central plan in any form is particularly apt to convey symbolic

\footnotetext{
2 Geometric symbolism is discussed in Callisto (1997).

3 One of the most popular examples of this intensification is the little church Tempietto di San Pietro in Montorio in Rome by D. Bramante (1502).
}

functions. So it has also been applied - in commemorative structures - to honour saints, heroes, and other important persons, scientists among them. Completely useless for housing, office, or industrial production buildings, it could be and was applied to religious cults, as well as a base for astronomical observations.

The most excellent central plan is circle for it has uncountable number of symmetry axes and represents thus multifold rotational symmetry. The examples are prehistoric Stonehenge (2500 B.C.), pre-Slavonic Stone Circles (Kamienne Kręgi) in Odry (Pomerania) (1300 B.C.), Temple of Vesta in Tivoli (700 B.C.). Pantheon in Rome (114-126 AD) and similarly the later Cenotaph of Newton by É.-L. Boullée (1784), both based on sphere, represent an exceptional centrality in three dimensions.

Equilateral polygons were applied in the Middle Ages. Dodecagon can be observed e.g. in Liebfrauenkirche in Trier (Germany) (1242) and Santa Vera Cruz church in Segovia (Spain) (12th/13th c.). Octagon constitutes the plans of San Vitale in Ravenna (6th c.), Baptistery in Florence (12th c.), San Lorenzo in Turin by G. Guarini (1668), and also timber Orthodox churches in the territories of the former Polish-Lithuanian Commonwealth, where Greek cross arms were added to the basic octagon. Hexagon underlies Romanesque Sechseckkapelle in Comburg (1230) and Matthiaskapelle in Kobern (1220-1240). Square gave form to the so called marabouts built in the Arab countries as tombs of persons considered holy; to nine-field plan of Orthodox churches where axis mundi notion inside is enhanced by the vault system while outside by the cupolas; and equally nine-polar Jewish synagogues in the former Polish-Lithuanian Commonwealth. All the great religions: Judaism, Islam, and Christianity in similar way approach central layout in architecture, i.e. rotational symmetry in building plan.

But it is with equilateral triangle that the impassable limit is reached for the centralised plan.

\section{Equilateral triangle as a base for central plan}

Equilateral triangle applied to a building plan represents an extreme form of centralised plan. While circular plan in its ideal form has infinite number of symmetry axes (multi-rotational symmetry), triangular plan has only three symmetry axes. Less axes, i.e. two, a central plan cannot have because two axes crossed at the right angle, at the same time either enforce the existence of two other diagonal axes (Greek cross), or compel to abandon centrality (Latin cross).

Triangle is also fascinating because of its minimal number of elements. A plane figure cannot be built with less than three sides, and that is why no such building 
plan can even be drawn. Triangle also has a specific structural aspect. One does not have to be a civil engineer to notice that the form of a triangle made of any three rods cannot be changed without breaking one of them. Triangle makes a perfectly rigid and stable system. Trusses and other construction elements (lattice frames) exist as bearing structures only because of inherent triangles provided by struts and other bracing elements.

Equilateral triangle stands out among other triangles. It is the simplest one, both to be outlined and to be built. Once drawn it becomes an easy to spot, conspicuous sign. Any three stones laid loosely will be concerned as accidental setting, if however they would be laid in equal distances to each other, as vertices of an equilateral triangle, one would perceive such a layout to be the result of one's deliberate, conscious action (Llanfechell - 001) (Fig. 1).

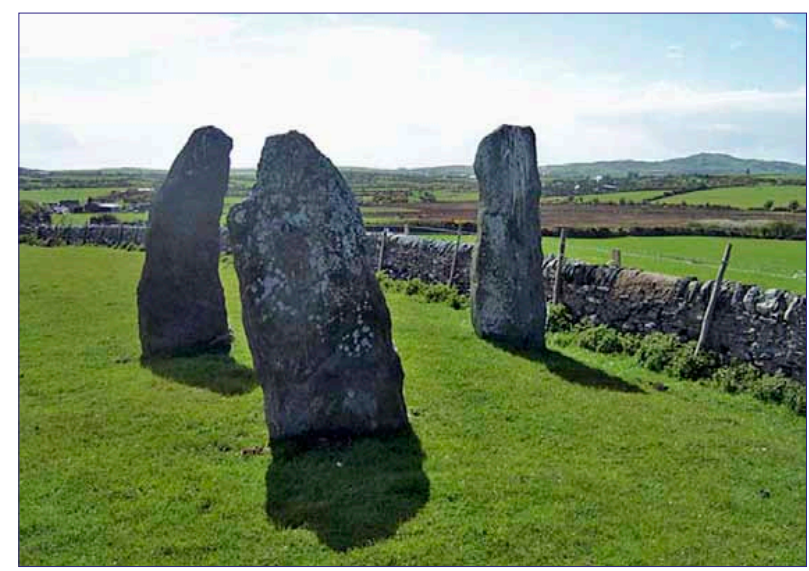

Fig. 1. Llanfechell near Amlwch (Anglesey). Three megalithic menhirs (Llanfechell Triangle), Neolithic Period, ca 3000 BC. Source: http://www.themodernantiquarian.com/site/127/mein hirion.html - posted by Iron Man.

\section{Architectural space on triangular plan}

\section{Obvious functional problems inside}

Centralised composition is rational on the condition that its shape would be well exposed and exploited semantically. In a sacred building the form itself invites to put an accent in the centre by placing the altar there. However in the Western Christian church such solution has never been popular.

Equilateral triangular plan, in which centralised polygonal layout reaches its climax, is exceptionally unpractical in the functional (utilitas) sense, both to arrange, and in daily use. Walls converging at an acute angle of $60^{\circ}$ make any attempt to furnish the narrowing space difficult - with standard furniture in particular. The wedge-shaped vanishing space is also difficult to keep up.
For this reason one of the main points of analyses and discussion are vertices of the basic triangle and their physical solutions. Usually, the inner corners are usually cut off with straight line of a partition assigning the uncomfortable space as a service room. This action transforms the central space into an equi-, or non-equilateral however usually regular, hexagon, and in consequence it leads to blotting out the perception of triangularity of the interior (Biesiady - 010; Greater Svorotva - 028 and 038).

Apses, inscribed in the corners of the basic triangle, and open to the central space are another way to improve the utility of the interior. Perception of the resulting space depends on the size of the apses; the smaller apses the better perception of the interior as a triangular one (A. Pozzo - 016). Large apses usually are added to an equilateral hexagon of the central nave (Waldsassen - 009, (Fig. 2); J. F. de Neufforge - 035). Thus the basic triangle ceases to be tangible, and it becomes perceivable as a spherical one in the vaults.

The edge of the external corner

An edge where two walls meet at the angle of $60^{\circ}$ may cause some difficulty in execution and conservation. In any case every narrow edge is fragile and sensitive to damage. Therefore, usually the very vertex in the analysed objects is:

- cut with straight line to obtain a narrow vertical piece of wall which flattens the meeting angle to $120^{\circ}$ (Bruck-an-der-Mur - 003; Kalwaria Zebrzydowska - 006; Andělská Hora - 013 (Fig. 3); Góra Św. Anny - 035);

- rounded with a convex curve (Stróża - 033) (Fig. 4): masonry buildings built of stone and bricks and plastered have their edges rounded or blunted;

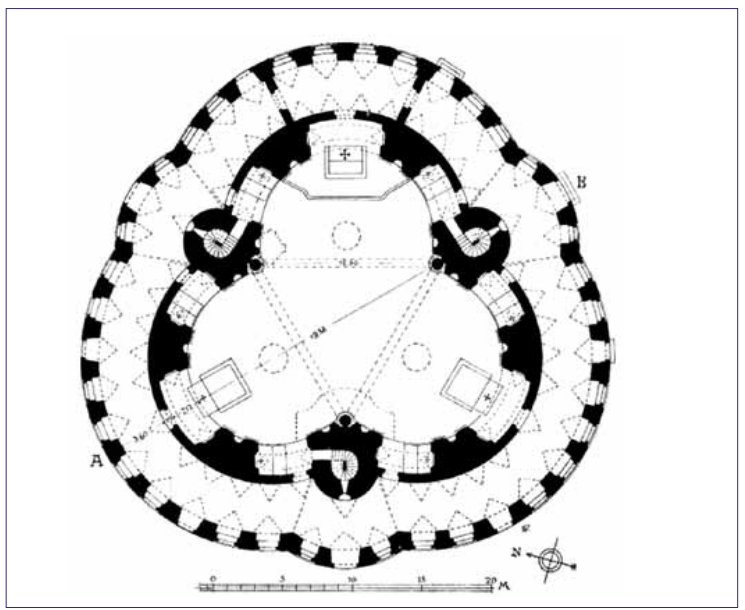

Fig. 2. Waldsassen, Glasberg, pilgrim church Holy Trinity Kappl, Georg Dientzenhofer, 1685. Plan. Source: Hempel. Here after: Norberg-Schulz 1966, fig. 96. 


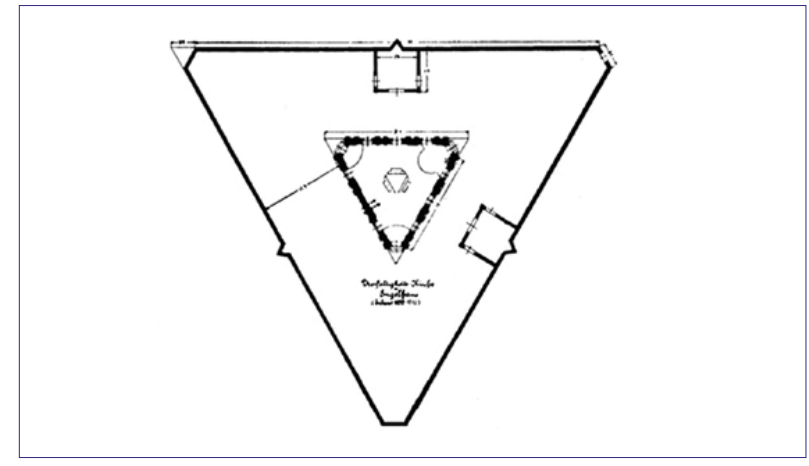

Fig. 3. Andělská Hora. Holy Trinity church, G. H. Alliprandi, 1696-1702. General plan after Gustav Kutschera 1908. Source: http://www.pamatkyaprirodakarlovarska.cz/andelska-horakostel-nejsvetejsi-trojice/.

- rounded with a concave curve (monastery by A. Pozzo - 016; Mikulàšovice - 025) (Fig. 5);

- rather rare cases have edges faithful to geometry, depending mainly on the material. In general stone (Rushton - 004 (Harbison 1992); Chlumec - 011 (Fig. 6)) and timber (Biesiady - 010; Greater Svorotva (timber) - 028) buildings are more apt to keep their geometrical exactness. Contrary to stone, timber buildings are difficult to preserve, and only one of those has survived today (Degučiai - 032) (Jankevičiene 1998).

- other, unique, individual solutions: an original solution, the only one among the objects listed in the Appendix, is found in Svorotva Vialikaya (masonry) (038) (Fig. 7). Even if for practical reasons the vertices are blunted with straight line, triangularity of the church is strongly accentuated by columns set in the very vertex points. It is a solution full of invention - semantically perhaps the best one.

\section{The exterior clarity}

Equilateral triangle has the quality of being easy to spot. As a plane figure it becomes a strong form ${ }^{4}$ in almost any surroundings, it stands out with its simplicity of shape. Application of a triangular plan because of its semantic potential, in spite of its functionally troublesome shape, makes sense on the condition that the shape is visible, and thus easy to be noticed. The triangular shape is quite a rarity among buildings, thence it is even easier to perceive.

\footnotetext{
4 Żórawski (1963) proposed a general typology of forms in architectural composition, based on Gestalt psychology. Strong form is a form that stands out in its surroundings of other forms (in contrast to weak form that does not stand out in its surroundings). Cohesive form is a form the parts of which are strongly tied among them and with the whole (form) (in contrast to free form where the parts are loosely tied among them and with the whole).
}

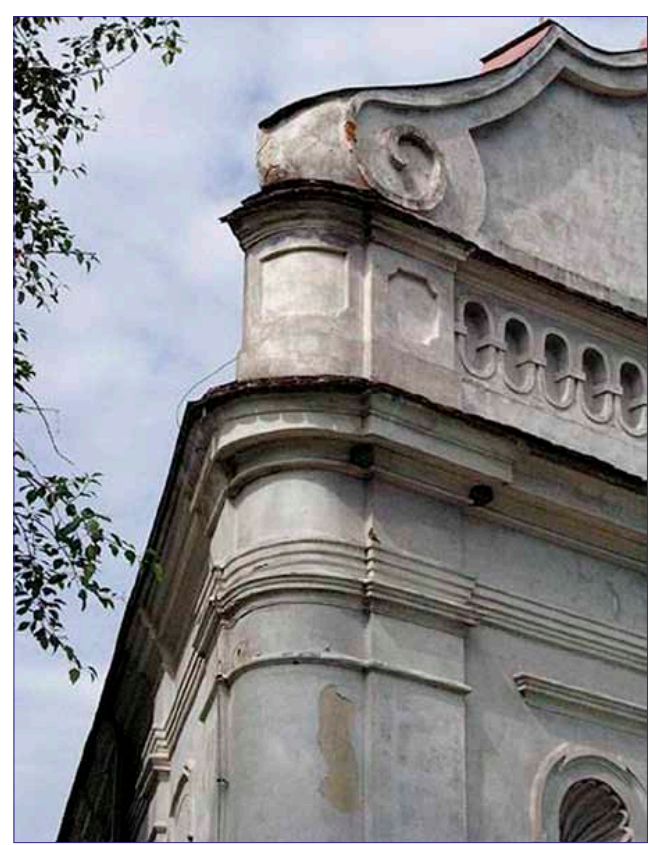

Fig. 4. Stróża k. Kraśnika. Holy Trinity church, J. Horsz, 1766-1767. Detail of the corner. Photo: J.-K. Lenartowicz 2005.

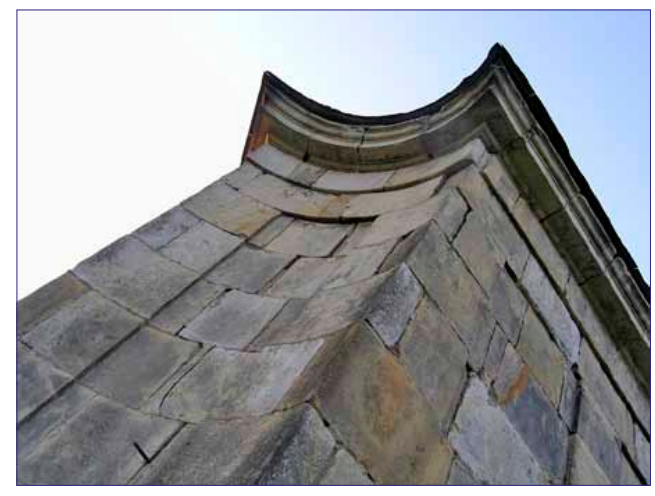

Fig. 5. Mikulašovice. Holy Trinity chapel U pěti lip, Z. Hofmann, 1741-1742. Detail of the corner. Photo: J.-K. Lenartowicz, 2007.

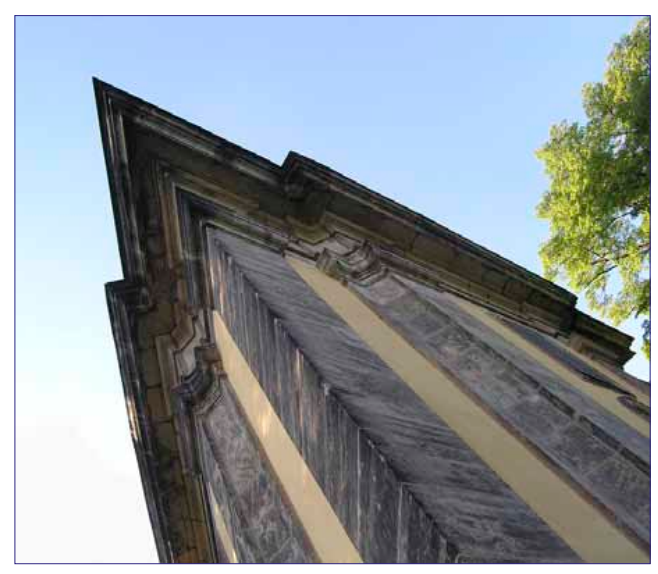

Fig. 6. Chlumec u Chabařovic (Kulm), Holy Trinity chapel na Horce, 1690-1691. Corner detail. Photo: J.-K. Lenartowicz 2007. 


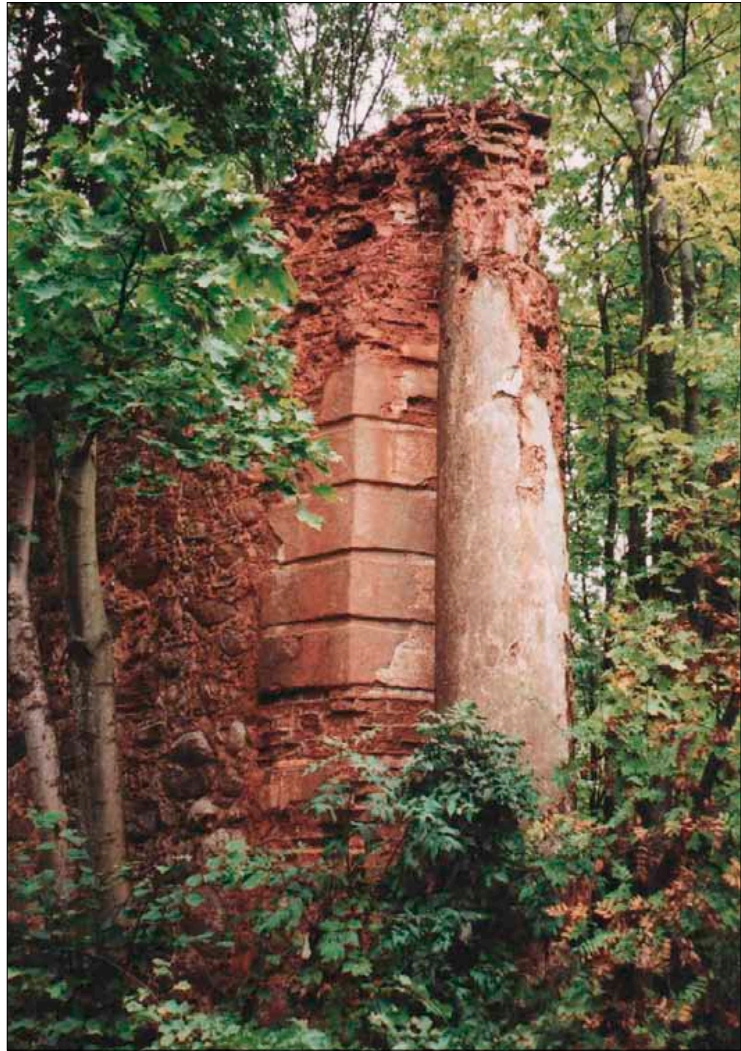

Fig. 7. Svorotva Vialikaya. Holy Trinity Uniate church (masonry), 1823. The column in the Southern corner. Photo: J.-K. Lenartowicz 2002.

In respect to the clarity of the triangular basic idea, there are several possibilities:

- Open work objects, where from the very first glance three basic elements (pillars set on the vertices of the triangle) are visible (Llanfechell - 001 (Fig. 1); Valtice - 039; Wiele - 041; Pittsburgh - 043; Poltava 047 (Fig. 8)). The clarity of the form is at its best.

- Objects with no interior space - solid pillar wayside shrines (Way of the Cross stations in Trhove Sviny - 016; Česky Brod - 025).

- Objects possessing interior volume that are perceived either from the outside, or the inside, but never at the same time (majority of the churches and chapels).

- Objects that evidently camouflage their basic triangle in various ways. The triangle remains the core of the spatial composition, but in order to support interest of the viewer, or just to augment superficial attractiveness, is deformed or hidden. To such interventions deforming the basic triangle belong:

- walls set on convex (when viewed from the outside) arches (Planès - 002; Münster - 026);

- walls set on concave arches (Panenské Břežany 018 (fig. 09); Rozsochatec - 020; Nadryby - 023; Neufforge - 036);

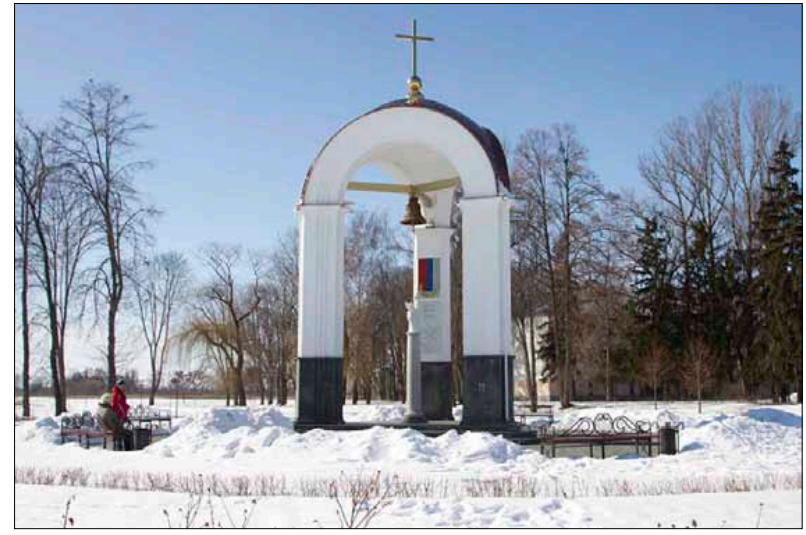

Fig. 8. Poltava, Poltava Battlefield. Belfry-chapel, 2009. General view. Source: http://www.charity-ukraine.privat-online. net/polt_bat.html.

- core structure surrounded by apses and galleries (Waldsassen - 009 (Fig. 02); Trhové Sviny - 017; Dommelstadl - 027);

- folded outer walls that do not reflect the inner structure, and are designed rather to play with light and shadow (Stadl-Paura - 019).

- Some buildings are deprived of a volume that could be visible from the exterior; their triangularity can be perceived only from inside (Rome - 007; Turin - 008).

- Triangularity is well demonstrated in the buildings that externally are faithful to the geometry (Rushton - 004; Biesiady - 010; Chlumec - 011 (Fig. 6); Degučiai - 032; Greater Svorotva - 028). In most cases the interior is laid out in a manner different than the exterior.

\section{Symbolic virtues of triangular geometry}

Visual effect of equilateral triangle geometry balances the functional and building technology drawbacks. Here, the point is not in the number of symmetry axes or their rotations but in the number of walls that enclose the space. These are three and cannot be less than three. The feeling of enclosure in case of a triangular space is much stronger than that in a rectangular or even isosceles one.

Such a shape could not remain unnoticed; in particular by the architects of late Renaissance and Baroque who enjoyed the play with mathematics and geometry (G. Guarini, F. Borromini, J.-B. SantiniAichel (Horyna 1998), K. I. Dientzenhoffer). The rigidity of the triangle as structure may be used to transmit the structure's meaning. Rigidity plus triple nature of the equilateral triangle constitute a potential which, when applied in a Christian shrine resonates 
in theology, and creates architecture parlante ${ }^{5}$. It has been only natural to associate such a building with the Holy Trinity.

\section{The theological aspect}

Symbols are axes of narration in sacred architecture of monotheistic religions (Wierzbicka 2013: 171). Therefore church buildings on equilateral triangular plan are "symbols of theological order" (Hani 2005). Architecture has taken advantage of the semantic capacity of the simple and easy to remember triangular form. In the Christian faith the triangular shape is associated with the Holy Trinity, i.e. the unity of God Father, Son and the Holy Spirit. Therefore many of the catalogued triangular objects are bound with the patrocinium of the Holy Trinity.

The Christian culture recognizes yet another trinity, namely the representation of Saint Anne, her daughter Maria, and the child Jesus. This representation is in a number of languages bound with a special name expressing trinity: Święta Anna Samotrzecia - in Polish (literally translated, „St. Anne with two other persons“, i.e. Madonna and Child with Saint Anne); Sankt Anne selbdritt - in German; Metterza - in Italian; Anne Trinitaire - in French; Ana Samotretja in Slovenian. This patrocinium inspired the architect to design a chapel on the equilateral triangular plan (Panenské Břežany - 018 (Fig. 9)).

\section{The patrocinium of the Holy Trinity and the borderland situation between Eastern and Western Europe}

Religion is not able to free itself from being involved in politics. This fact has intensively influenced the sacred architecture in Central-Eastern Europe. In the course of history a group of three Uniate shrines attracts attention: the church in Biesiady (010) and the two churches built one after another on the same spot in Greater Svorotva $(028,038)$ in Belarus. Further research is needed to be able to put on the same list also the Catholic churches in Samogitia, presently known by their patrocinia different from the Holy Trinity (Jesus Crucified church in Panevežiukas (1747) (030)

\footnotetext{
5 Post-modernism attracted attention to semiotics of architecture, which as a branch of architectural theory has developed in the 1980s. At that time a considerable number of papers were published concerning the relationship of form and meaning in architecture. To earlier ones belong: Sedlmayr (1948) and Norberg-Schulz (1963). The latter states that objects of culture are represented in architecture in two ways: 1) by an abstract sign or characteristic attribute (symbolization based on convention), or 2) through structural similarity. To illustrate the latter N.-Schulz recalls Dreifaltigkeitskirche in Waldsassen (009).
}

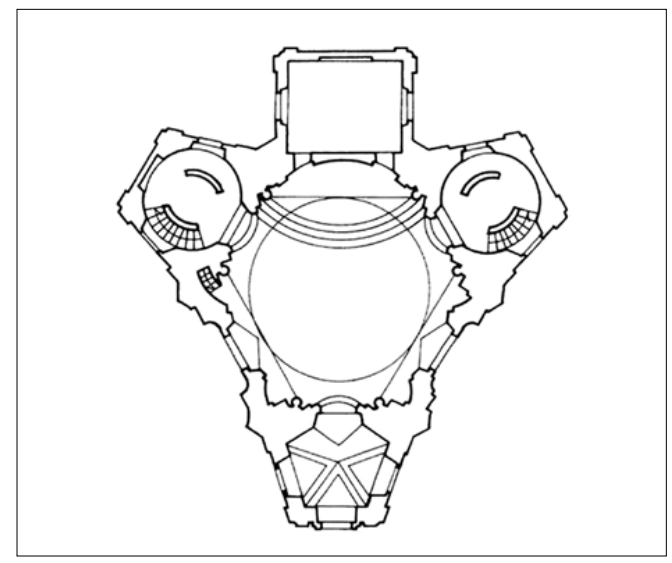

Fig. 9. Panenské Břežany. Chapel of St. Ann, Madonna and Child, J. B. Santini-Ajchel, 1705-1707. Ground floor plan. Source: Horyna, 1998: 226.

and the timber St. Vincent Ferrer church in Degučiai $(1757)^{6}(032)$, the latter being the only now preserved timber church based on equilateral triangle in Europe. These shrines lie scattered along the former borderland between Russia, Ukraine and the Polish-Lithuanian Commonwealth, the land, which at the same time had been a buffer zone between Western Europe with the Latin rite of the Roman-Catholic Church, and Eastern Europe with its Greek rite of the Orthodox Church. Unfortunately, both churches got involved in political transactions between the neighbouring countries, dominated by Russia tending to seize other countries. The Holy Trinity, due to the long lasting dispute between the Roman-Catholic and the Eastern Orthodox Church might have become a substantial motive on the meeting line of the two Churches.

\section{Holy Trinity and Filioque}

An extensive discussion concerned the interpretation of the major religious notion related to the Holy Trinity, known as Filioque ${ }^{7}$, i.e. "and the Son" - the theological formulation of the Holy Spirit's descent both from the Father and the Son, consequently "through the Son", but not directly from the Father. This formulation was introduced to the symbols

6 The church in Degučiai has been having various patrocinia: in the period 1763-1805 - the Immaculate Conception of Saint Mary; later inventories tell about the Holy Trinity; its present denomination was given on the turn of the $19^{\text {th }} / 20^{\text {th }}$ c. (Aleksadravičiūte 2004). It is not excluded that the original patrocinium (1757-1763) might have been the Holy Trinity too. After the recently carried out renovation of the building several papers have been published on the subject: Aleksandravičiūte (2004); Surdokaitè, G., "Degučių bažnyčios liturginiai rūbai, indai ir kiti reikmenys". Both texts are available in the Internet: (c) www.llt.lt, Lietuvos lokaliniai tyimai, ISSN 2029-0799.

7 See: Encyklopedia katolicka [The Catholic Encyclopaedia], vol. 5. Lublin, KUL 1989, Entry: Filioque. 
of faith by Western Church, but Eastern Orthodox Church as a non-canonical addition rejected it. It is considered to have been one of the causes of the Eastern Schism and thus it has become the subject of the ongoing theological dispute. Nowadays, it is one of the topics of the ecumenical dialogue (Huculak 1996).

After the religious Union of Brest in 1596 the two rites were united in the Uniate church, which is GreekCatholic rite. The Holy Trinity patrocinium became a symbol that in a best way reflected the specificity of the new Uniate church as an institution and as a building ${ }^{8}$ along the line of unity. The Orthodox Church involved in political intrigues of the tsarist Russia remained hostile.

These facts allowed Sergachev (1992) to put forward his hypothesis, supported by this author (Lenartowicz 2005), that efforts had been taken to develop a specific type of church building to mark the new Uniate worship (and the political difference), and to attract Orthodox worshippers to the West.

Since the end of the $18^{\text {th }} \mathrm{c}$. the political impact of Russia kept causing limitations of possibility to experiment new type of space, which would visually characterize church buildings and make the shrines that uniting the Eastern and Western rites stand out.

Proving the hypothesis demands further research both in the realm of architecture (provenance, founders, builders), church history and Christian religious dogmas.

\section{The Uniate church and the equilateral triangular plan}

The Uniate church in Biesiady (010) may only be discussed on the basis of the description of the later church - probably the latter's twin sister church - in Svorotva Vialikaya (028) as far as the spatial solution is concerned. Sergachev (1992: 193-194) also represents such an opinion. It might have been a regular but nonequilateral hexagon. Dependable and more detailed data exist on the latter building in a visitation description ${ }^{9}$. Sergachev gives a reliable reconstruction

\footnotetext{
8 Sergachev (1992: 195) writes: "the triangular form of the church plan [...] expressed not only a defined religious symbolism, but also the builders' aspiration to create an Orthodox church architecture that, remaining within the tradition, would not be too similar to the [Catholic] church architecture, what was demanded by the government and spiritual powers, after the Uniate Council in Zamość in 1720".

9 "The Protocol of the General visitation of the Cyryn and Novgorodek Deanery conducted by Rev. Tomasz Woszczełłowicz, delegated visitor in the year 1798", in Archeograficzeskij sbornik dokumentow otnosiaszczychsia $k$ istorii Siewiero-Zapadnoj Rusi, izdawajemyj pri uprawlenii Wilenskogo Uczebnogo Kruga [Archeo-geographical collection of documents related to the history of North-Western Russia, edited by the Vilna Scientific Circle], vol. XIV, Vilna 1904: 116ff.
}

drawing of the church ${ }^{10}$. An important feature of the object is the faithful - in the vertices' detail - realization of the simple geometrical idea.

Clearly, the present masonry church in Greater Svorotva is typologically identical with the timber on $\mathrm{e}^{11}$. The the solution of the vertices by introducing classical columns is extremely striking. The image of three pillars on which the roof structure rests is a most apt, simply perfect representation of the divine persons, under whose name remains the church. Is it not?

\section{Freemasonic traces}

The church in Svorotva had been ascribed to the Freemasonic idea ${ }^{12}$. Probably referring to this statement Sergachev (1992: 195) wrote:

"One of the scholars wrongly concluded that this church owned its unusual architecture to Freemasonry. The church is a clear example of transferring the forms and the methods of carpentry into stone architecture, a proof that in provincial regions of Belarus, even during the flourishing Classicism architecture, carpentry continued to affect stone-building. This can bee explained by continuation of the architectural and building tradition and by broad participation of carpenters in the building process. One should surely note that the effect of stone architecture on the forms and techniques of carpentry was much stronger in this period".

Although it is not possible to prove the Freemasonic provenance of the Uniate church in Svorotva Vialikaya, or at least a Freemasonic usage of it, one cannot fully agree with the above quoted argument. For in the masonry church of 1823 the solutions for its vertices with vertical columns certainly did not result from any log structure carpentry tradition.

The quality of the concept, execution and detailing of this small church might have contributed much to the opinion that for a certain period it was a Freemasonic lodge. One should observe that the solution of the church's vertices demonstrates a great mastery in architectural design, and mastery in building trade (Fig. 10). The vertices do not lose their triangularity despite their minimal cut-off. Classical order columns, put on the

\footnotetext{
10 Sergachev 1992: 194.

${ }^{11}$ Ibid.

12 See: J. Żmigrodzki, Nowogródek i okolice [Novgorodek and its environs]. $3^{\text {rd }}$ edition, by Nowogródzki Oddział Polsk[iego] Tow[arzystwa] Krajoznawczego, 1931: 92-93. Entry: Svorotva Wielka. The author does not provide any source but writes: "the Orthodox church of uncommon form, the plan of which presents an equilateral triangle (ancient Masonic lodge)".
} 
vertex points, solve with high excellence the difficult (as already mentioned) problem of any building set on a triangular plan.

\section{The scope of the study - a review}

Si les triangles faisaient un Dieu, ils lui donneraient trois côtés

Montesquieu ${ }^{13}$

Objects described in this paper have been designed and erected in various places in Europe. Not all of them belong to Christian culture and religion. It is not possible to draw a development line of their architecture, because each of these objects is unique, resulting from its author's approach to "triangularity" and the functional, i.e. liturgical, purpose of the building, present, among other aspects, in the building's patrocinium. In geographical terms the dispersion of such objects in wide: from French-Spanish border to Petersburg, and from Anglia to Austria. An exception is the case from Pittsburgh, Pennsylvania. Most of the cases are concentrated in Central-Eastern Europe (Czech Countries, Germany, Austria, and Poland). As to the time arrow, the oldest example is dated 3000 B.C. while the most recent 2009 A.D., but the highest building activity for the building type discussed here occurred in the $17^{\text {th }}$ and $18^{\text {th }}$ centuries. The review presented in this paper has been based on an earlier work of this author (Lenartowicz 2005). The set of triangular buildings known to him has now been enlarged by a dozen of new entries. Appendix to this paper presents a list of the identified objects in the chronological order of their creation.

From pre-Christian times comes the menhir in Llanfechell (001) - a megalithic centralized cult space (Fig. 1).

The set clearly shows that Middle Age did not accept the triangular plan as rational. One can mention only three very different objects, faraway one of the other: the castle chapel in Annecy (002) (12 ${ }^{\text {th }} \mathrm{c}$.), resulting probably more from morphology of the triangular end of the island than from a preconceived design idea; the mountain church in Planès (002) in France $\left(13^{\text {th }} \mathrm{c}\right.$.), and the hospital church in Bruck-an-der-Mur ${ }^{14}(003)$ in Austria $\left(15^{\text {th }} \mathrm{c}\right.$.).

Two unconnected objects represent the 16th c.: the lodge in Rushton (004) in Anglia, and the way-side shrine in Šaštín-Stráže (005) in Slovakia.

\footnotetext{
${ }^{13}$ Charles-Louis de Secondat (Montesquieu), Les lettres persanes, 1721 .

14 See: Götz 1968. This author expresses his gratitude to Meinhard and Ute Neugebauer, architects in Bruck an der Mur, for enabling access to the object.
}

In the $17^{\text {th }}$ c. the number of objects grew rapidly: in Poland: the early Way of the Cross in Kalwaria Zebrzydowska (007); in Italy: the churches in Rome by F. Borromini (008) (Connors 1996), and in Turin by G. Guarini (009); in Germany: the pilgrim church in Waldsassen G. Dientzenhofer (011) (Fig. 2); in Czech Republic: the memorial chapel in Chlumec (012), and the church in Andělská Hora by G.H. Alliprandi (013) (Fig. 3); in Lithuania: the no longer existing timber church in Biesiady (010); also the French calligraphic project by $\mathrm{T}$. Gobert (014).

The flourishing and the relative popularity of the triangular plan comes in the next century. As far as number is concerned Czech countries took the lead with the pilgrim church in Trhove Sviny (016), the chapel in Panenské Břežany (017) (Fig. 9), the project for Rozsochatec (020), the college in Rychnov nad Kněžnou (021), the chapel in Ostružno (022), the chapel in Nadryby (024) - all designed by J.B. Santini-Aichel (Horyna 1998), and:). the chapel in Mikulašovice by Z. Hofmann (026) (Fig. 5). In Austria: the church in Stadl-Paura by J. M. Prunner (019); in Germany: the monastery church in Münster by J. C. Schlaun (027), and the visually less obvious church in Dommelstadl (030); in Hungary: the church in Aba (031) and the chapel in Gyöngyös (034); in Lithuania: a group of three objects which now are object of closer analysis: the timber church in Greater Svorotva (028), the churches in Panevėžiukas (029) and in Degučiai ${ }^{15}$ (032); in Poland: the church in Stróża ${ }^{16}$ by J. Horsz (033) (Fig. 4), and the Way of the Cross chapel in Góra św. Anny (018); and in Anglia: the design for sepulchral church in Tyringham Hall by J. Soane ${ }^{17}$ (035); in Russia: the unexecuted church in Korostino (near Novgorod) by G. Chiaveri (023).

At the very beginning of the $18^{\text {th }}$ century (1700) A. Pozzo published a pattern-book containing, among others, project of a church and monastery (015); in the $2^{\text {nd }}$ half of the century J.-F. de Neufforge followed Pozzo and published (1780) his own pattern-book containing, among others, two triangular temples (035 and 036); active are J. B. Santini-Aichel, G. Chiaveri, C. Schlaun. In the swarm of wayside shrines built over all Europe since the $18^{\text {th }}$ century, among unpretentious, small and bigger, sometimes difficult to find and identify, solid, or having an interior, there is a group of objects on the

\footnotetext{
15 See: Aleksandravičiūtè 2004: 26-33.

16 See: Kowalczyk 1992.

17 J. S. Gero, R. M. Reffat, "Multiple representations as a platform for situated learning systems in designing". University of Sydney, Sydney 2000, Knowledge-Based Systems 14(2001): 337-351. Also: (J. Soane, Sir, Sepulchral Church), The London literary gazette and journal of belles lettres, arts, sciences, etc., (903), 395 p.
} 
equilateral triangle plan. It seems that later in time the fascination - if there was any - with equilateral triangle died away.

Masonry church in Svorotva Vialikaya (032) (Fig. 10), and the forest chapel in Valtice by G. Wingenmüller (033) were built in the $19^{\text {th }} \mathrm{c}$. several objects.

In the $20^{\text {th }} \mathrm{c}$. there was little interest in the difficult plan, just few objects were built: one station of the Way of the Cross in Wiele by T. Mayr (034), and the memorial belfry-chapel in Poltava (047) (Fig. 8); the church in Halle by W. Ulrich (042), the church in Hyvinkää by A. E. Ruusuvuori ((044), the church in Burg and der Alz by O. A. Gulfbransson (045), and the

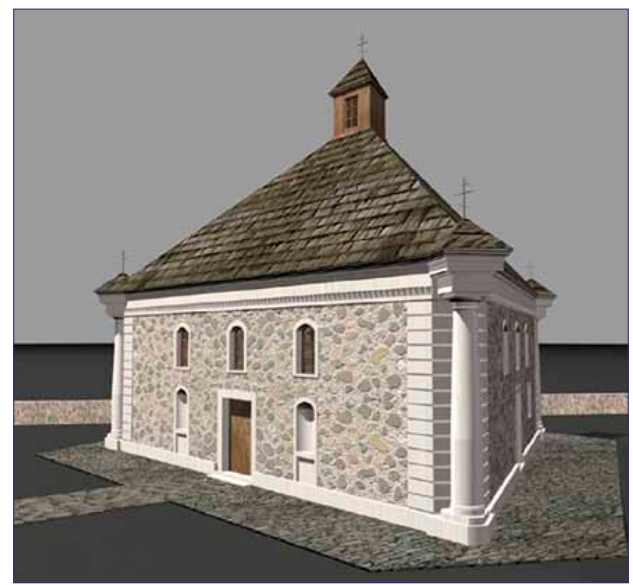

Fig. 10. Svorotva Vialikaya. Holy Trinity Uniate church (masonry), 1823. General view. Visualisation according to Sergachev 1992 and local vision of the state of repair. Restitution: J. Czubiński. Visualisation: J. Tucholska, 2002.

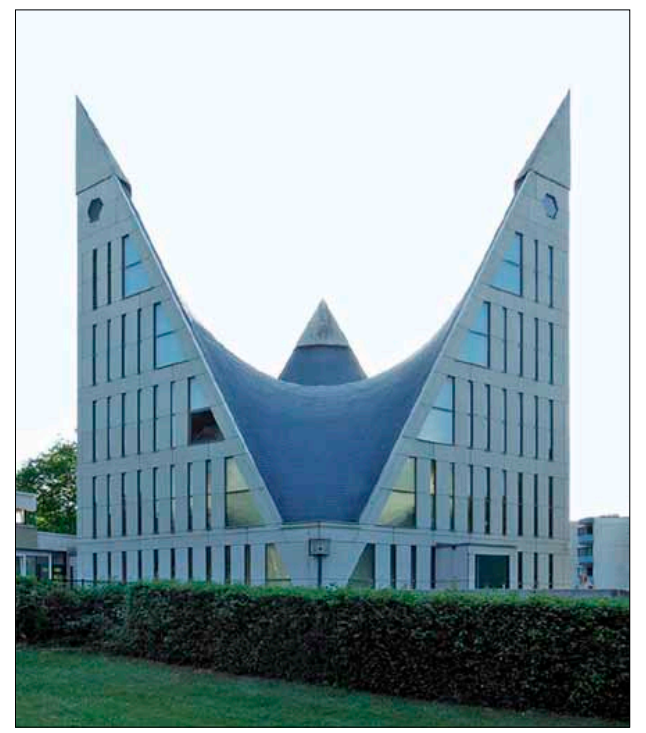

Fig. 11. Berlin-Siemensstadt. Holy Trinity Evangelical church, Reinhold Barwich, 1969. General view. Source: https://www. flickr.com/photos/33027180@N00/14184619499/in/poolphoto_graphics - photo: Martin Maleschka. church in Berlin-Siemensstadt by R. Barwich (046) (Fig. 11). P. Gösch designed his crystalline pilgrim church (040) (Fig. 12), and W. Huff his baptistery (043).

The relationship between shape (form) and idea (symbolic and other meaning), and triangle, "triangularity", and trinity, the latter related above all to the Holy Trinity, was intensively exploited. It is not by chance. The theological programme of $47 \%$ of the presented objects is related to trinity - 21 of the total 47 objects bear patrocinium of the Holy Trinity, one is devoted to St. Anne, Our Lady and Child Jesus.

\section{Discussion}

The Form. Due to its geometry and topologic extremity, the equilateral triangle stands out among the spatial solutions based on the central plan. This extremity obviously attracted architects' attention, despite difficulties it always entails; however in a sacral edifice, where the comfort of use is not of paramount importance, it was of lesser significance. Over centuries however, the group of such designs and erected structures has been slowly growing.

Insofar as all structures are, in a certain sense and scope identical in the formal sense, then their quoins allow the space for details to be shaped individually, as demonstrated on examples of specific structures. Neither the structures themselves nor the conditions for their construction are connected. The only exception is the output of the same author (e.g. J.-B. SantiniAjchel).

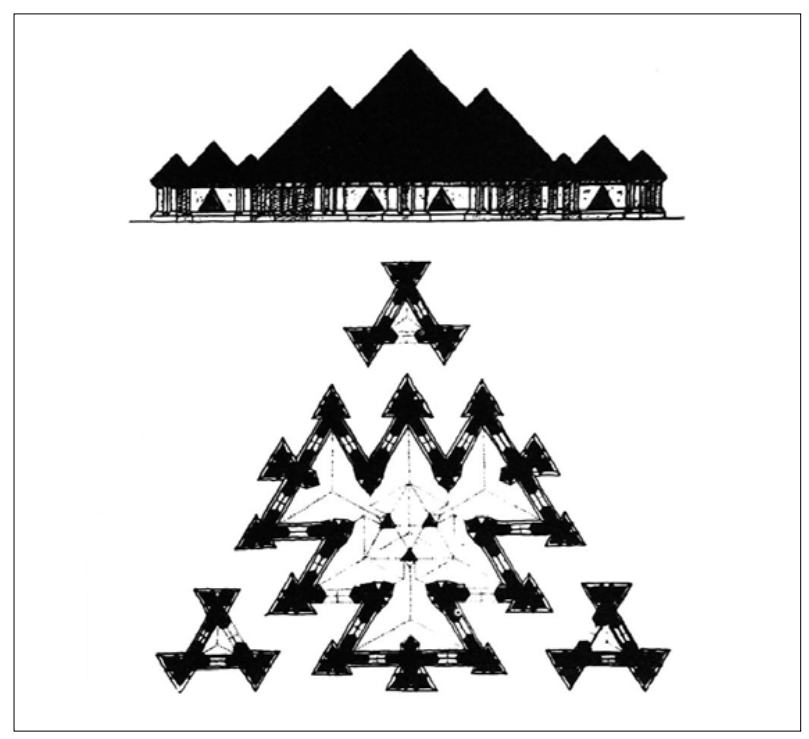

Fig. 12. Pilgrim church, Paul Gösch, 1920. Project. Source: W. Pehnt, Die Architektur des Expressionismus. Hatje, Stuttgart 1975: 39, figs. 60 and 61. 
Symbolism. A structure of the shape thus defined is very characteristic, which imbues it with a significant potential for semantic influence as well as a symbolic message.

The triangle is known as "the only self-stabilising polygon" (according to the term used by R. B. Fuller), a "rigid" figure, not prone to deformations. The triangle's resistance to changes vests it with a constructional, but also symbolic power.

The information concerning the Uniate Church in Svorotva Vialikya may be connected to the simultaneous use of the building as a Masonic lodge, but this is undoubtedly connected to its shape reminiscent of a trowel. What the truth was, we may never find out.

In Christian Europe, the equilateral triangle symbolises more than mere power. The invocation to the Holy Trinity is a natural content programme, inspiring to provide solutions on such a plan. Architects were not afraid to resort to the simplest form of symbolism - the equilateral triangle, which best reflected the equality of all Divine Persons. The patrocinium of the Holy Trinity is indeed frequently used in relation to these structures.

In the context of the dispute over Filioque, the reference to the Holy Trinity is probably of substantial significance on the line of contact between the Eastern and Western Church. This is so, since it was nowhere else that the Union of Brześć was established to join Catholicism with the Orthodox Church, whereas the invocation to the Holy Trinity may have been a good pretext to express specificity of the new church. Would the Uniate church have been triangular, as Sergaczew suggests? This question will remain without an answer as well.

Usually we imagine God anthropomorphically, as we know that we are created "in God's image and likeness". Montesquieu ironizes on the anthropomorphism of God's images, relativizing Man's place on Earth. His motto related to physical triangular forms devoted to the Holy Trinity brings another flavour. A three-walled shrine presents God's image in an abstract way, puzzling with its simplicity and straightforwardness.

\section{References}

Aleksandravičiūtė, A. 2004. Duktè Naumiesčio bažnyčios..., Menotyra 36(3): 26-33.

Callisto, R. (T. Roberti) 1997. Mystical Meaning in Sacred Western Architecture [online], [cited October 2014]. Available from Internet: http://members.aol.com/ Sabrin1315/arch.htm

Connors, J. 1996. S. Ivo alla Sapienza: the first three minutes, Journal of Architectural Historians LV: 38-57.

Eberhard, J. P. 2007. Architecture and the brain. A new knowledge base from neuroscience. Atlanta, Greenway Communications.
Eberhard, J. P. 2009a. Brain landscape. The coexistence of neuroscience and architecture. New York, NY, Oxford UP.

Eberhard, J. P. 2009b. Applying neuroscience to architecture, Neuron 62(6): 753-756.

Götz, W. 1968. Zentralbau und Zentralbautendenz in der gotischen Architektur. Berlin: Gebr. Mann Verlag.

Hani, J. 2005. Le Symbolisme du Temple Chrétien. Paris: Édition Véga.

Harbison, R. 1992. The built, the unbuilt, and the unbuildable. In pursuit of architectural meaning. Cambridge, Mass.: MIT Press, 70 p. (2nd printing).

Horyna, M. 1998. Jan Blažej Santini-Ajchel. Karolinum, Praha.

Huculak, O. B.; OFM. 1996. Duch Ojca i Syna według rdzennej teologii greckiej [The Spirit of the Father and Son according to the indigenous Greek theology]. Kraków, Wydawnictwo Zakonu Pijarów, 16ff.

Jankevičiene, A. 1998. Architektura drewnianych kościołów na Żmudzi w XVIII w [The Architecture of timber churches in Samogitia in the 18th c.], Sztuka pograniczy Rzeczypospolitej w okresie nowożytnym [Art of the borderland of Rzeczpospolita in the modern era]. Warszawa: Arx Regia, 217 p.

Kowalczyk, J. 1992. Architektura sakralna między Wisłą a Bugiem w okresie późnego baroku [Sacral architecture between Vistula and Bug rivers in the period of late Baroque], ch. 8. Kaplice [Chapels], Dzieje Lubelszczyzny [History of Lublin region], vol. VI, part III, Między Wschodem a Zachodem. Kultura artystyczna [Between East and West. Artistic culture]. Lublin: PWN.

Lenartowicz, J. K. 2005. Sacred space on the triangular plan. The Holy Trinity Uniate Church in Greater Svorotva, Belarus, in Sacrum in Architecture and Life Space. Poznań, Behavior, Environment, Architecture (3): 83-100.

Lenartowicz, J. K. 2009. Trójkąt równoboczny i Trójca Święta. Przerwany projekt architektoniczno-teologiczny kościoła unickiego? [Equilateral triangle and Holy Trinity. Interrupted architectural-theological project of the Uniate church?], in The 2nd International Scientific Conference "Architektura kultur lokalnych pogranicza. Architektura miejsc kultu i pamięci narodów i religii" [Architecture of local cultures in borderlands. Architecture of cult and memory places of nations and religions], 2-4 October 2009, Białystok-Vilna. Unpublished.

Lenartowicz, J. K. 2013. Equilateral triangle plan in European church architecture, in ISIS Congress-Festival Symmetry: Art and Science, Special Theme: Labyrinth and Symmetry, 9-15 September 2013, Bali, Crete.

Norberg-Schulz, Ch. 1963. Intentions in architecture. Oslo, London: Universitetsforlaget, Allen \& Unwin, 168ff.

Norberg-Schulz, Ch. 1971. Existence, space and architecture. London: Studio Vista.

Sedlmayr, H. 1948. Architektur als abbildende Kunst, in Sitzungberichte der Akademie der Wissenschaften. Wien.

Sergachev, S. A. 1992. Belaruskoe narodnoe zodchestvo [The Belarussian folk architecture]. Minsk: Uradzhay.

Wierzbicka, A. M. 2013. Architektura jako narracja znaczeniowa [Architecture as semantic narration]. Warszawa: Oficyna Wydawnicza Politechniki Warszawskiej.

Żórawski, J. 1963. O budowie formy architektonicznej [On the structure of architectural form]. Warszawa: Arkady. 


\section{A catalogue of the sacred objects based on equilateral triangular plan}

001. Llanfechell near Amlwch (Anglesey). Three megalithic menhirs (Llanfechell Triangle), Neolithic Period, circa 3000 BC (Fig. 1).

Plan: an almost perfect equilateral triangular plan.

002. Planès (Roussillon), church Nôtre Dame de la Merci, $12^{\text {th }} / 13^{\text {th }} \mathrm{c}$.

Layout: spherical equilateral triangle. The sides of the triangle have very flattened arches, protruding outside. Apsidioles are found in the middle of each side. The one with the altar is oriented towards the East. The entrance is located in the opposite, Western apex of the triangle, between the apex and the Southern apsidiole.

003. Annecy (Haute-Savoie). Palais de l'Isle chapel, $12^{\text {th }} \mathrm{c}$.

Layout: regular triangle, resulting from the shape of the island on which the entire palace stands.

004. Bruck-an-der-Mur (Austria), former hospital church Heilig-Geist, 1422-1497.

Layout: based on an equilateral triangle the apexes of which are cut with straight lines forming an irregular hexagon.

005. Šaštín-Stráže (Slovakia), Our Lady Chapel, after 1564.

Layout: an equilateral triangle. There are six-sided pillars united with the main body in the corners, crowned with small pyramidal roofs on a hexagonal base.

006. Rushton (Northamptonshire). The Triangular Lodge, Thomas Tresham, 1593-1597.

Layout: an ideal equilateral triangle (Harbison 1992). The number three represents the symbolism of the Holy Trinity in the Lodge. The building has three walls 33.3 feet long, surmounted by three gargoyles. It has three floors, and a triangular chimney. There are three steep triangular gables (each surmounted by a three-sided finial at the apex). Each of the walls has three rows of three windows: semi-basement windows are small trefoils with triangular lights, the ground floor windows are in the form of a cross with 3 circular windows at the end of each arm (forming a diamond), the first floor windows are large trefoils with triangular and hexagonal openings. Nine angel figures hold pipes which discharge rain water off the roof. The inscription on the front entrance reads: 'Tres Testimonium Dant' ('there are three that bear witness') from St John's Gospel referring to the Trinity. Three Latin texts, each 33 letters long, run around the building on each facade.

007. Kalwaria Zebrzydowska (Poland). Way of the Cross, House of Annas chapel, Paul Baurath, 1609-1617.

Layout: equilateral triangle with the apexes cut by a straight line. The whole forms an irregular hexagon. Volume: the narrow sides of the hexagon are provided with rusticated pilasters. A 6-part vault covers the central space. There is a triangular light opening in the centre of the vault. A lantern with hexagonal body tops the 6-plane tent roof.

008. Rome. Church San Ivo della Sapienza, Francesco Borromini, $1642-1660$.

Layout: based on two intersecting equilateral triangles, which form the central regular hexagon. This refers to the mediaeval practice of defining architectural forms ad triangulum. Three apsidioles (among them the altar one) and, alternatively with them, three niches (including the one with the entrance) adjoin the hexagon. In the further spatial development, the altar triangle becomes less visible, and the triangle connected with the entrance predominates.

Volume: The entire spatial system, characteristic of the architect, is highly complex and sophisticated. The niches are marked in the upper part of the church by convex circular cornice sections protruding towards the centre, and thus cutting the apexes of one of the basic triangles. The altar triangle is less discernible because it is defined only by concave semi-circular sections of the cornice. The cornice as a whole demonstrates the basic (entrance) equilateral triangle with its straight-line sections, hidden in the complex structure of the church.

009. Turin. Chapel Santissima Sindone, Guarino Guarini 1668-1694.

Layout: centralised, based on an equilateral triangle. The nave interior is outlined on a circle. The apexes of the triangle are only marked with the small stars laid in the pavement: two placed in the centres of the two round vestibules, and the third in the opening of the exterior wall behind the altar set up on the longitudinal axis of the structure. The triangle is physically completed above, in the three arches bearing the base of the cupola.

010. Biesiady (Belarus). Uniate church of unidentified patrocinium, 1685 (pulled down 1922).

A description from 1880 allows for the layout to be reconstructed: (most likely) an exact equilateral triangle. The inside corners were cut off by straight walls, thus forming a hexagonal irregular nave. Service rooms, including the sacristy, are located in the corners. A three-sided altar (cf. Svorotva Vialikaya and Andělská Hora) was most probably located in the centre.

011. Waldsassen, Glasberg (Germany), pilgrim church Holy Trinity Kappl, Georg Dientzenhofer, 1685 (Fig. 2).

Layout: equilateral triangle with three tower cylinders set on the apexes. Three apses of a large radius are located between the towers. The apses open to the centre of the church with arches, which form a spherical equilateral triangle. There is a semi spherical vault in the apses above each of the three altars. Three columns in the points where the apses adjoin each other mark the position of the towers in the overall church structure. Number 3 dominates in all the elements of the church. The idea of the unity in the Trinity is demonstrated in the exterior by the 3 towers and 3 lanterns. The core of the church is surrounded by a gallery, which follows the outline of the central nave on a larger perimeter.

012. Chlumec u Chabařovic (German: Kulm) (Czech Republic), Holy Trinity chapel na Horce, 1690-1691 (Fig. 3).

Layout: equilateral triangle. Each of the exterior walls has a centrally located very flat protrusion flanked by pilasters set close to the corners. An entrance and a window are located above it in the centre of each wall. The cornice of a large horizontal width repeats the symbolic shape with high expression. The polygonal interior of the baroque chapel is vaulted with a polygonal cupola.

013. Andělská Hora (Czech Republic). Holy Trinity church, G. H. Alliprandi, 1696-1702 (Fig. 4).

Layout: centralised based on the equilateral triangle. The vertices of the triangle are cut in a straight line, forming an irregular hexagon. The shape directly evokes the meaning of the patrocinium of the church. The church is covered by flat pyramid shingle roof, and crowned with a small belfry covered 
by triangular metal sheet pyramid roof. Three entrances were arranged in the blunted vertices. Only the north one is open at present.

The semantic is augmented and intensified by the arrangement of the surroundings of the church. The site has the shape of an equilateral triangle, with a massive stone wall marking the edges. There is a smaller chapel bound with the wall in the middle of each side (the Southern one missing). The chapels are based on square plans with prismatic protrusions on the external side of the surrounding wall.

014. Plans of churches together making record of the name LOVIS LE GRAND. Thomas Gobert, ca. 1630-1708. Plan of the church forming the letter " $\mathrm{A}$ ".

The entire project consists of 11 drawings of symmetrical (mirror image) building layout. Each building layout is based on a letter and its mirror image, i.e. each letter forms one - the left one looking from the entrance side - half of each plan (with the exception of letters "O" and " $\mathrm{A}$ ", which are integral). The letter-layouts read in sequence spell LOVIS LE GRAND (Louis the Great). A closer look at each of the layouts allows one to observe that this has to do with church layouts. Notwithstanding the functional discomfort resulting from the necessity of subordinating the interior of the church to the exterior shape of a given letter, the majority of the drawings show an altar. The layout represented by the letter " $\mathrm{A}$ " is based on an equilateral triangle. The apexes of the side with the main entrance are provided with graphic serifs (most probably bases of church towers).

015. Church and monastery, project in: Andrea Pozzo, Perspectiva pictorum et architectorum 1700.

Church layout: exterior - equilateral triangle with the apexes blunted with convex circular arches of a small radius; interior equilateral hexagon of the central nave with three semi-circular apses attached to every second side of the hexagon.

Layout of the entire complex: a corridor, to which monk cells, other rooms, and staircases adjoin on the outer side, surrounds the church. The entire building complex keeps the exterior form of an equilateral triangle, with apexes blunted with concave circular arches of a large radius.

016. Trhové Sviny (Czech Republic). Pilgrim church of Holy Trinity, J. B. Santini-Ajchel, 1701-1710.

Layout: equilateral hexagonal star. Apses and perpendicular entrance protrusions alternatively close the sides of the hexagon. The apses above the roof of the church are accentuated with cylindrical towers topped by baroque spires. The entrance volumes have freestanding baroque gables, each decorated with volutes and a triangular window. The church is laid on a centralised layout and arranged according to its patrocinium - there are 3 altars, 3 gables and turrets, tripartite windows, 3 towers, and 3 bells. Three paths lead to the church.

The building is surrounded by an open polygonal arcaded gallery built 1712-1719, with three-tower gates square in plan located in the centres of the wings.

The interior: a spherical cupola with a 12 -sided opening in the centre, and a lantern on the roof vaults the nave. From a general view, the church resembles a Russian orthodox church by the articulation of the towers and their spires. The entire Baroque complex consists of a slightly remote chapel (former bath, in use until the end of the 19th century) with the layout and details based on an equilateral triangle, standing on a natural water spring, and of a lane leading through the fields accompanied by stone stations of the Way of the Cross. The stations are in the form of three-sided pillar shrines (an equilateral triangle in cross section) cut of single grandiorite blocks.
017. Panenské Břežany (Czech Republic). Chapel of St. Ann, Madonna and Child, J. B. Santini-Ajchel, 1705-1707 (Fig. 5).

Layout: the structure is based on an equilateral triangle the sides of which are concave from the outside, and the apexes cut with a straight line. In the three corners there are two staircases and the entrance. The interior is defined by an equilateral hexagon with an inscribed circle under the cupola. A rectangular sacristy behind the altar, added in 1738, adjoins the side, which connects the staircases.

Volume: Three chapels adjoin the main nave vaulted by a cupola on three pendentives - their number tells about the patrocinium of the chapel. Even if the basic disposition of the space is equilateral triangle, the space structure is more complex and intricate. The apexes of the triangle are centres of three 6 radius ells circles, which are tangent to the central nave 14 radius ells circles. This basic scheme with the use of further additional pentagons and of the principle of turning resulted in a precisely elaborated layout.

018. Góra Św. Anny (Poland). Way of the Cross, Palace of Annas chapel, Domenico Signo, 1709.

Layout: equilateral triangle with apexes cut with a straight line, forming an irregular hexagon.

019. Stadl-Paura (Austria), Dreifaltigkeitskirche church, J. M. Prunner, 1714-1724.

Layout: equilateral triangle. Interior organised on an inscribed circle with 3 apses that fill the apexes of the basic triangle. Square towers adjoin the apexes from the outside and contain service rooms, connected to the nave with narrow passages. To represent the Holy Trinity, the church has 3 entrances, 3 windows, 3 altars, 3 organs, 3 semi-cupolas, and 3 towers. There is also an equilateral triangular opening in the centre of the cupola.

020. Rozsochatec (Czech Republic). Chapel, 1714. Unbuilt.

Layout: equilateral triangle. Santini tried to enrich the surface of the sidewalls by adding concave projections only slightly protruding from the mass of the wall. Pilaster strips are located on every side of each projection. There are three entrances to the chapel, each with a window above, set in the centres of the projections. The volume is divided in two levels, the bottom one crowned with a cornice, the upper one being a Mansard type roof. The roof is topped with a three-sided lantern. Double concave volutes divide the exterior sides of the lantern. It is tipped with a spire bearing the symbol of the Holy Trinity.

The interior is based on a regular hexagon vaulted with a cupola, held by three pendentives. The sacristy, a spiral staircase, and a service room are located in the three corners. The interior is further divided into three chapels with three altars.

021. Rychnov nad Kněžnou (Czech Republic). Piarist college, J. B. Santini-Ajchel, 1714. Partially completed (one of the three planned wings).

Layout: equilateral triangle as the symbol of the Holy Trinity. The western wing of the college building adjoined the church presbytery. The North-Eastern and the South-Eastern wings possessed 3-axial projections.

The college wings were 11-axial, and had single-axial concave recesses at their ends. The blunted corners were equipped with 3-axial protrusions similar to those in the centre of the sidewalls.

The main portal was in the southern apex. The inner court had a vaulted cloister, also built on the layout of an equilateral triangle with blunted vertices. The building had 2 floors and a basement. 
022. Ostružno (Czech Republic). Holy Trinity chapel, J. B. Santini-Ajchel, 1720.

Layout: equilateral triangle with apexes cut out by a concave arch of a small radius. Protrusions of an equal height with the whole wall are located in the centres of the side walls, where the entrance doors are placed. There is a tripartite vault with a triangular opening over the nave in the centre, and a lantern above, which has triangular windows in the sidewalls.

023. Korostino near Petersburg (Russia). Orthodox church, Gaetano Chiaveri, 1722. Unbuilt.

Layout: centralised based on an equilateral triangle. No documentation on the project is accessible.

024. Nadryby (Czech Republic). Chapel, attributed to J. B. Santini-Ajchel, before 1725. Small tower with a later added chapel.

Layout: spherical equilateral triangle.

025. Česky Brod (Czech Republic). Wayside chapel, 1729.

Layout: equilateral triangle with cut apexes marked with corner pilasters. The two-level object has no interior. The upper level is set back and is lower in comparison to the bottom one. The three sidewalls and the cornice crowning the lower level are convex in layout. In both levels there is a shallow niche, cut in a trefoil form on each side. The upper level cornice is vaulted and bent following the curve of the roof edge. The roof covered with red ceramic tiles takes on the form of a flat cupola.

026. Mikulašovice (Czech Republic). Holy Trinity chapel U pěti lip, Z. Hofmann, 1741-1742 (Fig. 6).

Layout: equilateral triangle with apexes cut out by a concave circular arch of a small radius. Four paired pilasters articulate the sidewalls. There is an entrance portal with a semi-circular arcade in the centre of each side between the pilasters. The exterior is not plastered.

The chapel roof was covered with slate and has a stone lantern on top of which there is a double (Lotharingian) cross. The lantern was only a decorative element. Today the chapel is covered with copper sheets. Interior: equilateral hexagon with three altar niches.

027. Münster, Westfalen (Germany). St. Clemens hospital church of the Order of St. John of God, J. C. Schlaun, 1745.

Layout: the church was originally melted in between the monastery buildings, which made the original spatial disposition based on an equilateral triangle unclear. The centralised nave is laid on a circular plan. The main altar is arranged in the centre of one of the sides of the triangle in a shallow niche. The two remaining sides also are provided with such niches. The main entrance is on the same axis, in the opposite vertex of the triangle. The two side altars are placed in the remaining apexes and connected with the main altar by a common podium. In ideal vision, one should recognize an irregular swinging hexagon in the centralised interior space. Notwithstanding the curved outline, with its concave-convex swing, three flat planes of the sidewalls suggest the existence of an elusive equilateral triangle, the apexes of which lay beyond the building body, physically intangible.

028. Svorotva Vialikaya (Belarus). Uniate church (timber), 1747. Layout: an ideal equilateral triangle. The vertices of the triangle are cut with straight walls in the interior, so that the centralised nave takes on the shape of irregular hexagon. Service rooms, including the sacristy are located in the corners. A three-sided altar stood in the centre.
029. Panevėżiukas, Samogitia (Lithuania). Church of Jesus Crucified, 1747

Layout: centralised nave based on an equilateral triangle, small square rooms are located in the corners. Two of them open to the nave, flanking the main entrance, are crowned with roofs shaped as little towers. The third one in the opposite corner, behind the high altar, houses a rectangular sacristy behind which a vestibule is located.

030. Dommelstadl, Neuburg am Inn (Germany). Holy Trinity church (Dreifaltigkeitskirche), S. Goldberger, P. J. Köglsperger, J. M. Schneitmann, 1747-1751.

Layout: centralised space based on an equilateral triangle with an inscribed circle (cupola). Three apses with three semi-cupolas adjoin the triangle sides. The whole resembles the pilgrim Kappl in Waldsassen (011), however the spatial structure is visually not as clear as there. The three apses are visible in the outer view of the church suggesting its patrocinium, however the entrance portico and the single tower with a small onionlike spire blur the tripartite disposition of the church.

031. Aba, Fejér (Hungary). Holy Trinity church, 1753.

Layout: centralised nave on an equilateral triangle. The corners are rounded from the outside. There are two levels of balconies in the corners of the triangle, opening to the central nave. A cupola is placed over the centre. An entrance part rectangular in plan is added on the Western side.

032. Degučiai, Samogitia (Lithuania). Church of St. Vincent Ferrer, 1757.

The Holy Trinity patrocinium is mentioned in the later $19^{\text {th }}$ century inventories. The only timber church on equilateral plan preserved in Europe. Layout: ideal equilateral triangle (Jankevičiene 1998). There are box-like square additions (sacristy, depot, vestibule) in the centre of each side.

033. Stróża near Kraśnik (Poland). Holy Trinity church, Józef Horsz, 1766-1767 (Fig. 7).

Layout: equilateral triangle. The apexes are rounded with a small radius arch. A perpendicular box vestibule is added to the North-Eastern side. Spiral staircase is located in the eastern corner. Two pillars support the choir.

034. Gyöngyös (Hungary). Chapel of St. John of Nepomuk, 1776.

Layout: equilateral triangle with blunted apexes forming an irregular hexagon.

035. Temple of the Three Virtues or devoted to the Trinity, project in: Jean F. Neufforge, Supplement Au Receuil Elementaire D'Architecture. Paris 1780.

Layout: equilateral hexagonal central space adjoined by three semi-circular apses. The apses give the interior space triangular character, accentuated by the cylindrical pedestals in the centres of the apses. Three entrance portals are located between the apses. In the outside the structural pillars placed on the vertices of the hexagon are paired in two to form sides of a larger equilateral triangle the vertices of which lie far beyond the building. The sides are marked with two pairs of columns standing in line.

036. Temple of the Three Arts related to Architecture, project in: Jean F. Neufforge, Supplement Au Receuil Elementaire D'Architecture. Paris 1780. 
Layout: equilateral triangle the vertices of which are centers of three small circular interior spaces connected with a larger central rotunda. The three small spaces are encased in rectangular blocks set at $120^{\circ}$ to each other and joined by a concave wall. As its vertices are hidden the basic triangle is difficult to recognize. The whole layout resembles the chapel in Panenske Břežany (017).

037. Tyringham Hall, Buckinghamshire (Great Britain). Sepulchral Church, Sir John Soane, 1796.

Layout: equilateral hexagon resulting from overlaying two equilateral triangles. Semi-circular apses replace the apexes of one of the triangles; entrance porticos are located in the apexes of the other triangle.

038. Svorotva Vialikaya (Belarus). Holy Trinity Uniate church (masonry), 1823 (Figs 08, 09).

Layout: equilateral triangle with apexes cut off with a straight line. Entrance openings are located in the centre of each side. The hexagonal interior adjoins service rooms arranged in the corners of the triangle. The design of the exterior corners of the building is of particular quality - Tuscan order columns are located on the apex point.

039. Valtice (Czech Republic), Boži Les. Chapel of St. Hubertus, Georg Wingenmüller, 1854.

Layout: equilateral triangle. The structural pillars of the chapel are placed in the apexes of the triangle.

040. Pilgrim church, Paul Gösch, 1920. Project (Fig. 10).

Layout: the shrine complex is laid out on an equilateral triangle, built of smaller, also triangular, overlapping modules. These overlaps allow for the spatial units to be connected. There is a triangular nave space in the centre with three pillars laid out on the triangle. Three modules of side chapels adjoin the central space. Freestanding chapels of the size equal to one sub-module are set in the corners of the complex. Crystalline detailing is present throughout the whole. The entrance openings in the elevation are in the form of equilateral triangles. Individual modules, covered with pyramids, tower over the central nave in form of a high pyramid.

041. Wiele, Pomerania (Poland). Way of the Cross, Station of Flagellation, Theodor Mayr, 1923.

Layout: equilateral triangle. Three pillars set on the vertices of the triangle.

042. Halle (Germany). Holy Trinity church, Wilhelm Ulrich, 1930.

Layout: centralised space on an equilateral triangle with blunted apexes. The interior is an irregular hexagon. The altar is located in an adjoining space, also hexagonal, abutting on one of the shorter sides of the central nave hexagon, and open to it. There are columns, hexagonal in cross-section, set on the apexes of the altar space hexagon. They bear a baldachin that takes on the form of a hexagonal prism. There is large horizontal light stripe, which is not visible from the church space, behind and over the baldachin. The altar is indirectly lit through that opening. A lantern is set over the centre of the nave. There is no tower.

043. Pittsburgh (USA). Baptistery, St. Andrew Episcopal Church, William Huff, 1955. Project.

Layout: three adjoining equilateral triangles. Each of the modules is vaulted with a sphere sector. This gives semi-circular arcades in side views. The baptistery chapel is based on the Trinity motive - three triangular vaults.
044. Hyvinkää (Finland). Church, Aarne Emil Ruusuvuori, 1959-1961.

Layout: conjunction of two triangles: the larger equilateral one (main nave) and the smaller rectangular one (housing the entrance and other parish service rooms).

045. Burgkirchen an der Alz (Austria). Holy Trinity Evangelical church, Olaf A. Gulfbransson, 1960.

Layout: centralised space of the nave based on an equilateral triangle. The furniture (benches) arrangement supports the centralisation of the space grouping the faithful in a semi-circle. The lectern is placed in the very centre of the basic floor triangle. An entrance vestibule with stairs adjoins this triangle of the nave on one side, and a trapezoidal group of parish service rooms adjoins on the other. Three roof planes are also in the form of equilateral triangles, and build a pyramidal closing of the building.

046. Berlin-Siemensstadt (Germany). Holy Trinity Evangelical church, Reinhold Barwich, 1969 (Fig. 11).

Layout: equilateral hexagon. A rather pointed tower is placed in every second apex of the hexagon. The towers form an equilateral triangular system in the exterior of the church. There is a circular opening - the Eye of the God in the centre of the hanging roof.

There are staircases serving 3 levels of the inner galleries in two tower corners, and the pipe organ in the third one.

047. Poltava (Ukraine), Poltava Battlefield of 1709. Belfrychapel, 2009 (Fig. 12).

Layout: equilateral triangle. An open structure raised on three pillars placed in the apexes of the triangle. The pillars are connected with each other by means of semi-circular arcades. The arcades delineate the shape of the cupola vault.

\section{J. KRZYSZTOF LENARTOWICZ}

Faculty of Architecture, Cracow University of Technology, Ul. Warszawska 24, 31-155 Cracow, Poland. E-mail: klenart@pk.edu.pl

Prof. J. Krzysztof Lenartowicz, architect. Worked in Denmark, Switzerland and Libya. Since 1989 partner in STUDIO ARCHI 5 architectural design office in Cracow. Buildings: parish church in Jaworzno (completion of a 1938 building) (1970-1975); parish church in Wilkasy (1984-2010); Nürnberger Haus in Cracow (1994). Author and co-author of prize-winning and mentioned projects in international and Polish competitions. Teaching: Faculty of Architecture, Cracow University of Technology; Fachbereich Architektur, Fachhochschule Münster. Author: O psychologii architektury [On Architectural Psychology], Cracow 1994 (2nd ed.); Słownik psychologii architektury [Dictionary of Architectural Psychology], Cracow 2010 (4th ed.). Recent research: new approaches to revitalisation of post-industrial sites and buildings; REGENTIF 5th Framework Programme EC project (2003-2007). 